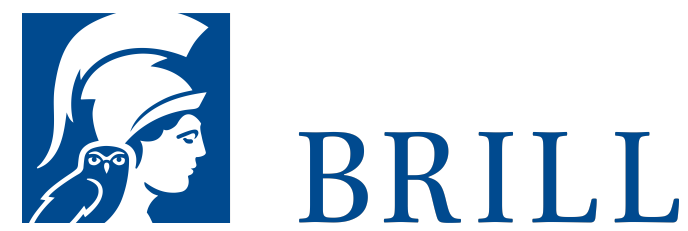

\title{
Lebendige Erkenntnis und ihre literarische Kommunikation
}

Robert Musil im Kontext der Lebensphilosophie

Author: Benjamin Gittel

Die Untersuchung versteht sich als Beitrag zu der in der Literaturwissenschaft, Philosophie und Wissenschaftsgeschichte geführten Debatte um die Darstellungsformen von Wissen bzw. das 'Wissen der Literatur', geht jedoch in zweifacher Hinsicht über diese hinaus. Zum einen zeigt sie, wie und warum die Forderung nach einer gegenüber wissenschaftlicher Erkenntnis alternativen, literarisch vermittelten Erkenntnis in einer bestimmten geistesund kulturgeschichtlichen Konstellation virulent wird: in der Lebens- bzw. Weltanschauungsphilosophie von 1870 bis 1930 sowie im Werk Robert Musils. Zum anderen nimmt die Arbeit eine Akzentverlagerung vor. Im Mittelpunkt steht nicht die oft mit unbefriedigenden Ergebnissen diskutierte Frage, ob Literatur generell, sondern unter welchen konkreten Umständen ein bestimmtes literarisches Werk Wissen vermittelt. Die nicht zuletzt mithilfe von Begrifflichkeiten und Einsichten der Analytischen Erkenntnistheorie formulierten Bedingungen, unter denen dies der Fall ist, ermöglichen schließlich exemplarische Analysen von Musils schriftstellerischen Versuchen, eine 'lebendige Erkenntnis' zu kommunizieren.

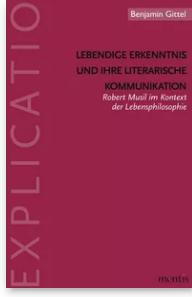

Pages: 498 Seiten

Language:

German

Subjects:

German,

Literature and Cultural Studies Publisher: Brill| mentis

Series:

Explicatio

E-Book (PDF)

Released online:

o1 Jun 2013

ISBN: 978-3-

$89785^{-851^{-0}}$

List price

Paperback

Publication date: o1 Jun 2013

ISBN: 978-389785-120-7

List price 
For more information see brill.com

Order information: Order online at brill.com +44330 333 0049 | customerservices@brill.com Submission information: brill.com/authors

Titles published by Brill | Fink, Brill | mentis or Brill | Schöningh: +49(o)715413279216| brill@brocom.de 